Dept.of Veterinary Sciences,

Faculty of Agronomic and Veterinary Sciences,

Ibn Khaldoun University, Tiaret, Algeria.

\title{
STUDY OF PROPORTIONAL LENGTH OF BONY SUBSTITUTION USING ORTHOTOPIC AUTOCLAVED ALLOGRAFT IN DOGS FEMUR
}

(With 2 Tables and 11 Figures)

\author{
By \\ KARIM AMARA; L. BOUKRAA; H. SHNAIN* \\ and M. MELLIZI** \\ * Surgery Department, Faculty of Veterinary Medicine, \\ Baghdad University; Iraq \\ ** Veterinary Sciences Department, Faculty of Sciences, \\ Batna University; Algeria. \\ (Received at 1/3/2009)
}

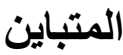

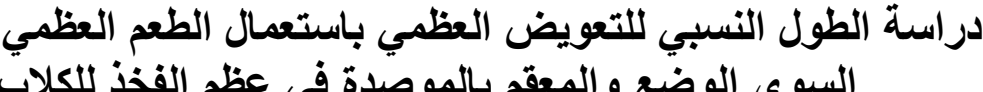

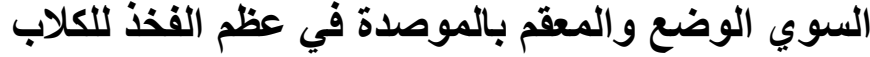
كريم عمارة ، العبإ بوكرع ، حهزة شنبين ، محد مبليزي

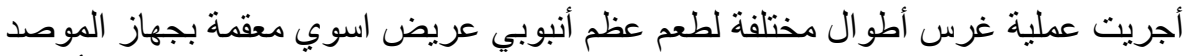

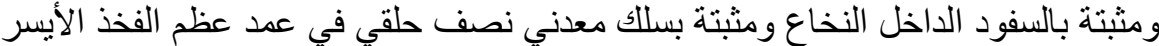

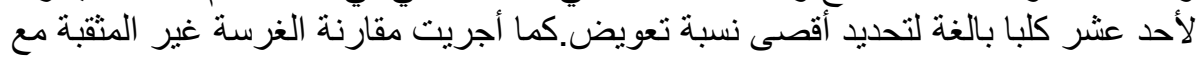

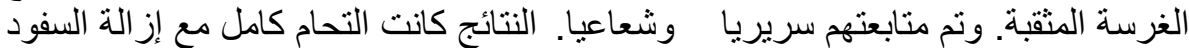

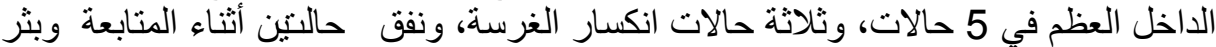

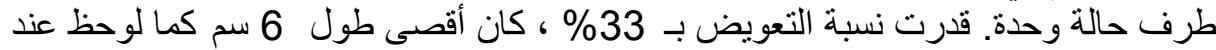

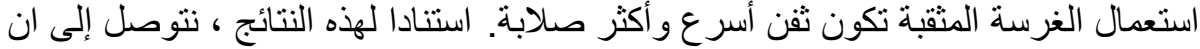
الطعم المنباين الاسوي المعقم بجهاز الموصد يتناسب هيكليا مع التعويض العظمي بمقدار حده النها 33 من الطول الكلي اللعظ.

\section{SUMMARY}

Implantation of different lengths of orthotopic autoclaved allograft in the femur of dogs fixed with intramedullary pin and stainless steel wire have been performed in $11 \mathrm{dogs}$, to determine the maximum percentage of bone substitution. Clinical lameness and serial post operative radiographs are evaluated, as well as, comparison of fenestrated and non fenestrated bony implants. Bone union has been observed in five dogs, 
fracture of the implant in three cases, limb amputation of one case, and death of two dogs during the follow up. The maximum percentage of the bony substitution that could be applied successfully is $33 \%$ with the maximum length of $6 \mathrm{~cm}$. The rapid hard callus formation has been observed after the use of perforated implant.

Key words: Bony substitution, orthotopic autoclaved allograft, femur, dog.

\section{INTRODUCTION}

The first successful autogenous bone graft in animals was recorded by Merrem in 1809 to 1810 in citations by Albee, Merrem obtained healing of bone plates which have been removed by trepanation subperiosteally (Albee, 1915). Since this first attempt the literature on the subject has grown prodigiously and contains a wide diversity of confusing opinions regarding the best type of graft and the fate of the graft after transplantation (Peer, 1955). Transplantation of bone repair skeletal injuries is a well-recognized surgical technique. Graft material has consisted of cancellous bone (Souter, 1969), cortical bone (Albee, 1923), or corticocancellous bone (Brinker et al., 1975). Autograft has been taken from the same individual (Enneking and Morris, 1972; Ranly et al., 2007), (allograft) from an individual of the same species (Henriksen, 1979; Ranly et al., 2007), and (xenograft) from an individual of a different species (Hamon, 1964; Ranly et al., 2007). The material used was fresh, stored, or processed. Bone grafts have loosely packed, or have been fixed within defects, using wires, pins, or plates (Wilson et al., 1985).

Allogeneic cancellous bone grafts is frequently used during orthopaedic surgery in humans. Considerable morbidity is associated with autogenous cancellous bone grafting in humans, including prolonged surgical and anesthetic time, increased blood loss, risk of infection, and structural damage at the donor site, and increased postoperative pain (Kerwin et al., 1996).

In veterinary medicine, allografts of cortical bone are readily obtainable and relatively inexpensive. They must be harvested and implanted under strictly sterile conditions (Friedlaender, 1983). For these reasons, and the fact that there are so many different sizes of dogs, we report in the present paper a new method of bony substitution using autoclaved allograft. 


\section{MATERIALS and METHODS}

\section{Experimental animals}

Eleven local breed dogs (three females and eight males), weighting 11 to $20 \mathrm{~kg}$, were used for the experiment. A presurgical treatment was applied for each dog using antiparasitic drug and then kept in special cages to avoid motion.

\section{Bone graft preparation}

The bones were prepared from femur diaphysis of Euthanized dogs. They were harvested under complete aseptic operating room conditions, and skin preparation. Routine orthopaedic operative draping and gowning procedures using towels, double muslin drapes and surgical gloving was used during all bone harvests. The bone was harvested minutes after the donor euthanasia. All muscles, bone marrow, and most of the periosteum were removed from the bone. Different lengths of bone grafts have been obtained from different donors to be used as substitute (Table 1). The harvested bone was double wrapped in muslin towels and autoclaved.

\section{Operation procedure}

Surgical procedure was performed under general anaesthesia using atropine sulphate $(1 \mathrm{mg} / \mathrm{b} . \mathrm{w})$ intramuscularly as preanaesthetic followed 10 minutes later by intramuscular administration of a mixture of xylazine $(5 \mathrm{mg} / \mathrm{kg})$ and ketamine $(15 \mathrm{mg} / \mathrm{kg})$. The animals were intubated and anesthesia was maintained with isoflurane (1-2\%), with spontaneous breathing.

Curved skin incision is made just cranial to the femoral shaft. The biceps femoris muscle is encountered if the incision is directly over the shaft. After approaching the femur by incising the facia lata cranial to the biceps muscle, the vastus lateralis muscle is retracted caudally to allow visualisation of femur segment. Maximal stripping of the periosteum is done to check the integrity of the femur shaft. The section length was measured by the prepared allograft. Appropriated length of the mid-diaphysis of femur was removed with an oscillating bone saw under constant irrigation with normal saline. The bone grafts were then inserted into recipient, and minor adjustments were made to provide maximum contact conformity between the graft and host bone segments. The fixation of the graft was assured by intramedullary pin and wire by suturing the proximal and distal interface.

The pin was placed in retrograde fashion, exiting proximally through the trochanteric fossa. The surgeon must extend the animal's hip 
joint and adduct the femur when passing the pin proximally to avoid the sciatic nerve as it passes over the great trochanteric notch. The pin was placed proximally before insertion of bone graft segment. Enough pin was used to fill the medullary canal at its narrowest point. The pin was then driven distally into graft segment first then distal host bone segment. The surgery site was irrigated with a sterile saline-neomycin solution. Soft tissue closure was routine.

Procaine penicillin G $(40,000$ units $/ \mathrm{kg})$ was administered intramuscularly following surgery, and ampicillin $(20 \mathrm{mg} / \mathrm{kg})$ was given per os every eight hours for the next 10 days.

The postoperative analgesic protocol included subcutaneous injection of buprenorphine $(0.02 \mathrm{mg} / \mathrm{kg})$ and intramuscular injection of oxymorphone $(0.02 \mathrm{mg} / \mathrm{kg})$ every $2-4 \mathrm{~h}$ for 2 days.

Radiography was performed immediately after surgery to evaluate the alignment between the host and grafted segment, and thereafter as dictated by the clinical and radiographic progression of union.

\section{RESULTS}

Table 1: Study design

\begin{tabular}{|c|c|c|c|c|c|c|}
\hline $\begin{array}{c}\text { Case } \\
\mathrm{n}^{\circ}\end{array}$ & Sex & $\begin{array}{c}\text { Body } \\
\text { Weight(kg) }\end{array}$ & $\begin{array}{c}\text { Percentage } \\
\text { of Bony } \\
\text { Substitution }\end{array}$ & $\begin{array}{c}\text { Graft } \\
\text { Length } \\
(\mathrm{cm})\end{array}$ & $\begin{array}{c}\text { Perforated } \\
\text { Graft }\end{array}$ & $\begin{array}{c}\text { Non } \\
\text { Perforated } \\
\text { Graft }\end{array}$ \\
\hline 1 & male & 15 & $42 \%$ & 8 & & $\mathrm{x}$ \\
\hline 2 & male & 13 & $43 \%$ & 7 & & $\mathrm{x}$ \\
\hline 3 & male & 12 & $33 \%$ & 5 & & $\mathrm{x}$ \\
\hline 4 & male & 17 & $33 \%$ & 6 & 6 & $\mathrm{x}$ \\
\hline 5 & female & 12 & $41 \%$ & 6 & & $\mathrm{x}$ \\
\hline 6 & male & 10 & $34 \%$ & 6 & & $\mathrm{x}$ \\
\hline 7 & male & 14 & $42 \%$ & 6 & & $\mathrm{x}$ \\
\hline 8 & male & 11 & $33 \%$ & 5 & $\mathrm{x}$ & \\
\hline 9 & female & 20 & $33 \%$ & 5 & & $\mathrm{x}$ \\
\hline 10 & female & 14 & $23 \%$ & 4 & 2 & \\
\hline 11 & male & 13 & $11 \%$ & 2 & & \\
\hline
\end{tabular}

Table 2: Clinical and radiographic data for 11 dogs which received different lengths of autoclaved allograft

\begin{tabular}{|l|l|l|l|l|}
\hline Case & $\begin{array}{c}\text { Type of } \\
\text { fixation }\end{array}$ & Complications & $\begin{array}{c}\text { Radiographic } \\
\text { Follow-Up }\end{array}$ & Clinical Follow-Up \\
\hline
\end{tabular}


Assiut Vet. Med. J. Vol. 55 No. 121 April 2009

\begin{tabular}{|c|c|c|c|c|}
\hline 1 & Pin & $\begin{array}{c}\text { Severe bone } \\
\text { instability } \\
\text { Limb amputation }\end{array}$ & $\begin{array}{l}\text { Postoperative } \\
\text { radiography }\end{array}$ & $\begin{array}{c}\text { Difficult weight bearing until } \\
\text { amputation }\end{array}$ \\
\hline 2 & $\begin{array}{l}\text { Pin and } \\
\text { wires }\end{array}$ & $\begin{array}{l}\text { Hemorrhagic } \\
\text { diarrhea } \\
\text { Died }\end{array}$ & $\begin{array}{l}\text { Postoperative } \\
\text { radiography }\end{array}$ & $\begin{array}{l}\text { Partial weight bearing during } \\
\text { the first week }\end{array}$ \\
\hline 3 & $\begin{array}{l}\text { Pin and } \\
\text { wires }\end{array}$ & $\begin{array}{l}\text { Died in the end of } \\
\text { the follow-up }\end{array}$ & $\begin{array}{l}\text { Complete } \\
\text { bridging } \\
\text { At } 3 \text { weeks }\end{array}$ & $\begin{array}{c}\text { Full weight bearing occurred } \\
\text { after two weeks }\end{array}$ \\
\hline 4 & $\begin{array}{l}\text { Pin and } \\
\text { wires }\end{array}$ & none & $\begin{array}{l}\text { Complete } \\
\text { healing at } \\
\text { proximal } \\
\text { interface }\end{array}$ & $\begin{array}{c}\text { Full weight bearing occurred } \\
\text { after three weeks / Pin } \\
\text { removed after } 42 \text { weeks }\end{array}$ \\
\hline 5 & $\begin{array}{l}\text { Pin and } \\
\text { wires }\end{array}$ & $\begin{array}{l}\text { Fracture of the } \\
\text { graft after } 20 \\
\text { weeks }\end{array}$ & $\begin{array}{l}\text { Normal callus } \\
\text { bridging/graft } \\
\text { fragility }\end{array}$ & $\begin{array}{l}\text { pin protruding / partial weight } \\
\text { bearing }\end{array}$ \\
\hline 6 & $\begin{array}{l}\text { Pin and } \\
\text { wires }\end{array}$ & $\begin{array}{l}\text { Complete Graft } \\
\text { resoption after } 18 \\
\text { weeks }\end{array}$ & $\begin{array}{l}\text { Severe graft } \\
\text { resoption/import } \\
\text { ant callus } \\
\text { formation }\end{array}$ & $\begin{array}{l}\text { pin protruding / partial weight } \\
\text { bearing }\end{array}$ \\
\hline 7 & $\begin{array}{l}\text { Pin and } \\
\text { wires }\end{array}$ & $\begin{array}{l}\text { Fracture of the } \\
\text { graft after } 8 \text { weeks }\end{array}$ & $\begin{array}{c}\text { Normal callus } \\
\text { bridging at distal } \\
\text { interface/graft } \\
\text { fragility }\end{array}$ & $\begin{array}{l}\text { pin protruding / partial weight } \\
\text { bearing }\end{array}$ \\
\hline 8 & $\begin{array}{l}\text { Pin and } \\
\text { wires }\end{array}$ & none & $\begin{array}{c}\text { Complete } \\
\text { healing at the } \\
\text { distal interface }\end{array}$ & $\begin{array}{l}\text { Full weight bearing/Pin } \\
\text { removed after } 16 \text { weeks }\end{array}$ \\
\hline 9 & $\begin{array}{l}\text { Pin and } \\
\text { wires }\end{array}$ & none & $\begin{array}{l}\text { Complete fusion } \\
\text { at the proximal } \\
\text { and distal } \\
\text { interface }\end{array}$ & $\begin{array}{l}\text { Full weight bearing /Pin } \\
\text { removed after } 16 \text { weeks }\end{array}$ \\
\hline 10 & $\begin{array}{l}\text { Pin and } \\
\text { wires }\end{array}$ & none & $\begin{array}{c}\text { Complete } \\
\text { integration at the } \\
\text { distal interface }\end{array}$ & $\begin{array}{l}\text { Full weight bearing } / \mathrm{Pin} \\
\text { removed after } 12 \text { weeks }\end{array}$ \\
\hline 11 & $\begin{array}{l}\text { Pin and } \\
\text { wires }\end{array}$ & none & $\begin{array}{l}\text { Important callus } \\
\text { formation }\end{array}$ & $\begin{array}{l}\text { Full weight bearing /Pin } \\
\text { removed after } 12 \text { weeks }\end{array}$ \\
\hline
\end{tabular}



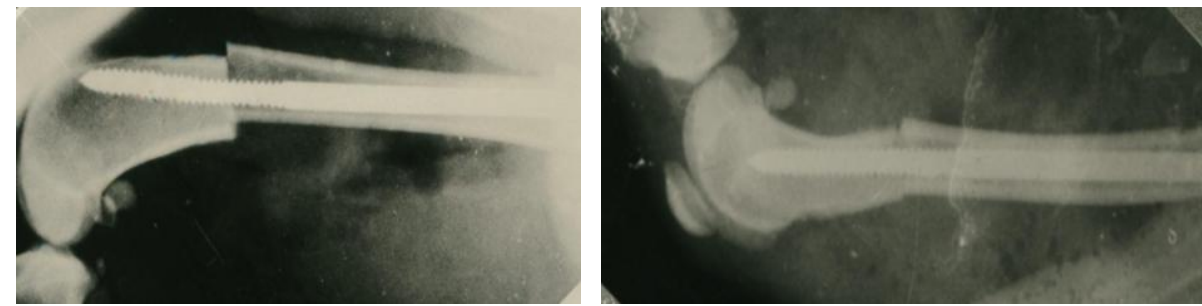

Case $\mathbf{N}^{\circ} \mathbf{1}$ (Postoperatively) fixation without using metallic wire $\underline{\text { Case } \mathbf{N}^{\circ} 2}$ (Postoperatively)
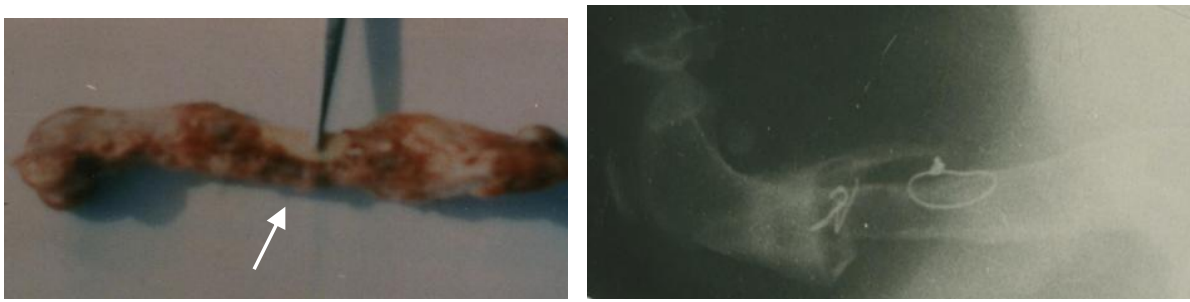

$\underline{\text { Case } \mathbf{N}^{\circ} \mathbf{3}}$ (After dissection) we can observe in this photo a complete callus bridging

$\underline{\text { se } \mathbf{N}^{\circ} 4}$ (After 46 weeks) we can observe a complete graft healing in the proximal interface after pin removal
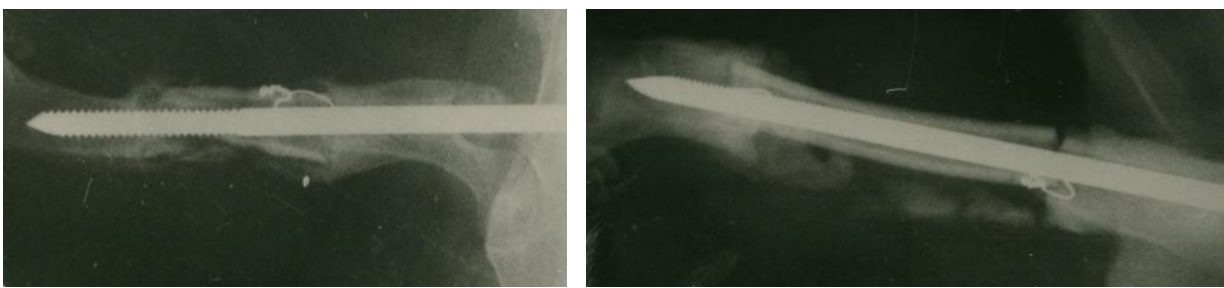

Case $\mathbf{N}^{\circ} \mathbf{5}$ (After 20 weeks) the fracture of the graft in his distal part $\underline{\text { Case } \mathbf{N}^{\circ} \mathbf{6}}$ (After 3 weeks) Partial callus formation with graft resorption
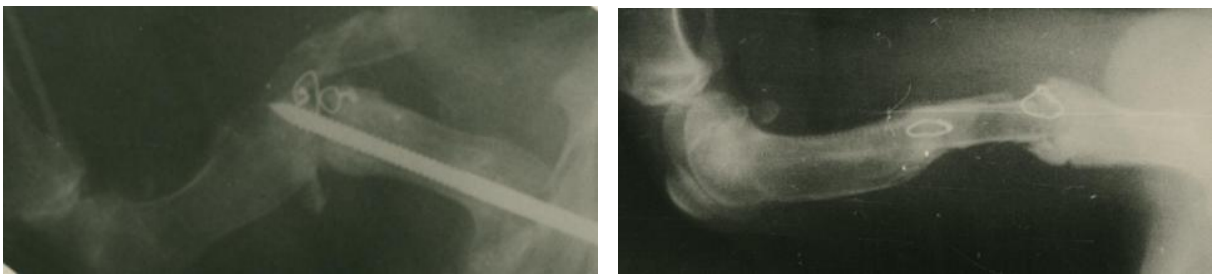

Case $\mathbf{N}^{\circ} \mathbf{7}$ (After 8 weeks) Complete graft fracture

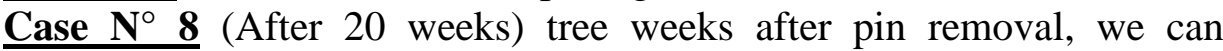
observe the complete disappearance of fracture line 

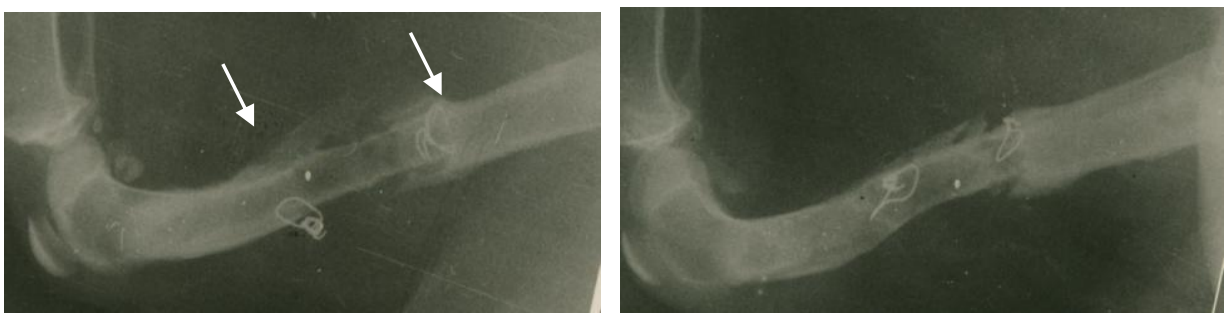

Case $\mathbf{N}^{\circ} \mathbf{9}$ (After 20 weeks) complete integration at the distal interface after pin removal

Case $\mathbf{N}^{\circ} \mathbf{1 0}$ (After 15 weeks) complete bone union occurred in each interface after pin removal.

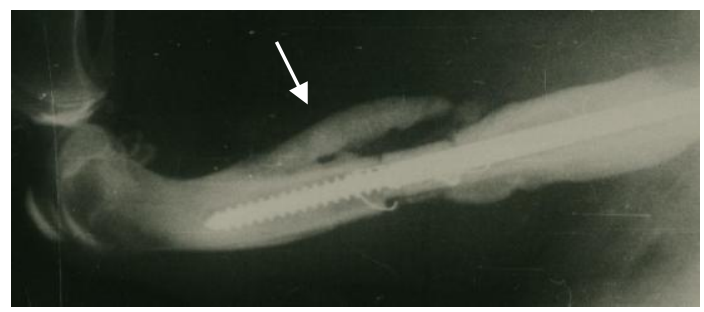

Case $\mathbf{N}^{\circ} \mathbf{1 1}$ (After 5 weeks) we can observe in this radiography the successful callus bridging in each interface.

\section{DISCUSSION}

The results in these 11 cases are summarized in chart form (Table 2). Total graft incorporation was observed in the cases $n^{\circ} 4,8,9$, 10 and11. Transient swelling of the limb at operative site was observed during the first post operative day in every dog. Each dog was bearing full weight on operated limb within two to four weeks following surgery except one (case $n^{\circ} 1$ ). In this case, the poor fixation using only pin without wire fixation produced limb rotation and permanent bone instability which prevented callus formation. The bone fracture and resorption were observed in the cases $n^{\circ} 5,6$ and 7. The complete callus bridging occurred after one month. During clinical follow up one dog had hemorrhagic diarrhea causing his death (case $n^{\circ} 2$ ), another died in the end of the experimentation (case $n^{\circ} 3$ ).

Bony substitution using segmental freeze dried and fresh cortical allograft has been performed with limited length for at least $5 \mathrm{~cm}$ (Albee, 1923; Schena et al., 1984; Schena et al., 1985). In retrospective analysis of failures in the repair of severely comminuted long bone fractures using large diaphysal allograft the successful canine allograft was $6 \mathrm{~cm}$ 
(Henry and Wadsworth, 1981) ${ }^{\mathrm{b}}$. Other studies of bony substitution with microvascular anastomosis mentioned the maximal length of $38 \%$ of the total femur length (Szentimrey et al., 1995).

In our study, the maximal successful length of autoclaved allograft was $6 \mathrm{~cm}$ which represented 33\% of the total femur length case $\mathrm{n}^{\circ} 4$.

The success rate for tubular allografts in the dog was 36\% (Henry and Wadsworth, 1981) ${ }^{\mathrm{a}}$. The success rate of the orthotopic autoclaved allograft was more important than the others $(45 \%)$.

The most serious late complication of bony substitution was the fracture of the graft (Delloye et al., 2004). In our study the fracture or high resorption of autoclaved graft was also the first problem cases $\mathrm{n}^{\circ} 5,6,7$.

The most common cause of delayed or non-union is inadequate fixation and instability at the fracture site (Boudrieau, 1994). Either the pins were loose in the intramedullary canal, causing pain, or the proximal end of the pins protruding into the gluteal mass was causing pain on use, or the close proximity of the pins to sciatic nerve, or a combination of all three caused the dysfunction associated with the intramedullary pin (Braden and Brinker 1973). Our results are in full agreement with this. The use of the intramedullary pin with wire fixation has provided high stability.

The formation of a progressive wall of periosteal as an attempt to bridge each interface usually started near the distal interface, this may have been due to the frequent problems of instability (Schena et al., 1984). Similar problem was observed in case $n^{\circ} 4$ with delayed callus formation in the proximal interface, complete healing occurred after 46 weeks.

It must be kept in mind that in patients who are heavy or very active the survival of the implant may be at hazard (Galante et al., 1975).The heaviest dog in our study was $20 \mathrm{~kg}$ (case $\mathrm{n}^{\circ}$ ) ) and the graft was fenestrated, this case showed normal bone healing.

Cortical union usually occurred shortly after complete periosteal bridging. The approximate time of cortical union at the proximal interface for the fresh cortical autograft (control) was 12 weeks and 15 weeks in both the freeze-dried and fresh cortical allograft. At the distal interface, these values were 11 weeks in fresh cortical autograft (control) and 18 weeks in the freeze-dried and fresh cortical allograft (Schena et al., 1984). In our study delayed union at the proximal 
interface has been observed in the cases $\mathrm{n}^{\circ} 4$ and11 and at the distal interface in cases $\mathrm{n}^{\circ} 8,9$ and 10 . The cortical union at the proximal interface occurred after 8 weeks in the case $n^{\circ} 11$ and after 12 weeks at the distal interface in the cases $n^{\circ} 8$ and 9 . In the case $n^{\circ} 10$ the cortical union at distal interface occurred after 13 weeks and after 18 weeks at proximal interface in the case $n^{\circ} 4$. The complete callus bridging with disappearance of fracture line was observed at 3 weeks, after bone dissection $\left(\right.$ case $\left.\mathrm{n}^{\circ} 3\right)$.

Ordinarily, fixation devices are removed only after radiography confirms clinical union. In most cases with diaphysal graft the bone plate was removed 18 months postoperatively (Braden and Brinker 1973). In the present study a partial weight-bearing was observed from the third day. After 12 weeks the pins were removed and the most dogs recuperated gradually a complete weight-bearing.

The use of fenestrated allograft has showed rapid callus bridging and high stability this is due to the penetration of the callus in the holes, and the contact of the internal and external callus. The fenestration didn't affect the graft resistance; this can be proved by the fact that the heaviest dog had the fenestrated graft. The fenestration disappeared rapidly after pin removal (case $\mathrm{n}^{\circ} 4,9$ and 10).

In Conclusion according to these findings, the orthotopic autoclaved allograft is determined to be structurally adequate for reconstruction of long bone, with a limit of $33 \%$ of total length, and the fenestrated bony implant is more suitable for the callus formation and fixation of callus than the non fenestrated. Intramedullary pin reinforced by wire suturing is adequate method for graft fixation.

\section{REFERENCES}

Albee, F.H. (1915): "Bone Graft Surgery" Philadelphia. W.B. Saunders Co., pp 18.

Albee, F.H. (1923): "Fundamentals in bone transplantation" J. Am. Med. Assoc., Vol 81, pp 1429-1432.

Boudrieau, R.J. (1994): "Delayed union; non-union and malunion" In Saunders Manuel of Small Animal Practice. Edited by S.J. Birchard \& R.G. Sherding, WB Sauders Co, pp 1096-1100.

Braden, T.D. and Brinker, W.O. (1973): "Effect of certain internal fixation devices on functional" J. Am. Vet. Med. Assoc., Vol $162, \mathrm{~N}^{\circ} 8, \mathrm{pp}$ 642-647. 
Brinker, W.O.; Flo G.L.; Braden, T. (1975): "Removal of bone plates in small animals" J. Am. Anim. Hosp. Assoc., Vol 11, pp 577586.

Delloye, C.; Suratwala, S. J.; Cornu, O. and Lee, F.Y. (2004):

"Treatment of allograft nonunions with recombinant human bone morphogenetic proteins (rhBMP)". Acta. Orthop. Belg., Vol. 70, pp. 591-597

Enneking, W.F. and Morris, J.L. (1972): "Human autologous cortical bone transplants" Clin. Orthop., Vol 87, pp 28-35.

Friedlaender, G.E. (1983): "Currents concepts review bone-banking" J. Bone. Joint. Surg., Vol 64A, pp 307-311.

Galante, J.O.; Rostoker, W. and Doyle, J.M. (1975): "Failed femoral stems in total hip prostheses" J. Bone. Joint. Surg., Vol 55A, pp 230-236.

Hamon, P. (1964): "Processed heterogenous bone implants as grafts in spinal surgery" Acta. Orthop. Scand., Vol 35, pp 98-116.

Henriksen, P. (1979): "Entire segment bone transplant in a cat" J. Am. Vet. Med. Assoc., Vol 174, pp 826-828.

Henry, W.B. and Wadsworth, P.L. (1981) ${ }^{a}$ : "Diaphysial allograft in repair of long bone fractures" J. Am. Anim. Hosp. Assoc., Vol 17, pp 525-534.

Henry, W.B., and Wadsworth, P.L. (1981) $)^{b}$ "Retrospective analysis of failures in the repair of severely comminuted long bone fractures using large diaphyseal allografts" J. Am. Anim. Hosp. Assoc., Vol 17, pp 535-546.

Kerwin, S.C.; Lewis, D.D.; Elkins, A.D.; Olivier, J. and Pechman, R. (1996): "Deep-frozen allogeneic cancellous bone graft in 10 dogs" Vet. Surg., Vol 25, pp 18-28.

Peer, L.A. (1955): "Transplantation of bone in animals" Transplantation of tissues, Vol II, Williams \& Wilkins Company, pp 152-179.

Ranly, D.M.; Lohmann, C.H.; Andreacchio, D.; Boyan, B.D. and Schwartz, Z. (2007): "Platelet-rich plasma inhibits demineralized bone matrix-induced bone for mation in nude mice" J. Bone. Joint. Surg. Vol.89, pp.139-147.

Schena, C.J.; Mitten, R.W. and Haefle, W.D. (1984): "Segmental freezedried and fresh cortical allograft in canine femur: I. A sequential radiographic comparison over a one-year time interval"J. Am. Anim. Hosp. Assoc., Vol 20, pp 911-925. 
Schena, C.J.; Graham, D.L. and Haefle, W.D. (1985): "Segmental freeze-dried and fresh cortical allograft in canine femur: II. A sequential histological comparison over a one-year time interval"J. Am. Anim. Hosp. Assoc., Vol 21, pp 193-206.

Souter, W.A. (1969): "Autogenous cancellous strip grafts in the treatment of delayed union of long bone fractures" J. Bone. Joint. Surg., Vol 51, pp 63-75.

Szentimrey, D.; Fowler, D.; Johnstinson, G. and Wilkinson, A. (1995): "Transplantation of the canine distal ulna as a tree vascularized bone graft" Vet. Surg., Vol 24, pp 215-225.

Wilson, J.W.; Rhinelander, F.W. and Stewart, C.L. (1985): "Vascularization of chip bone graft" J. Am. Vet. Res., Vol 46, $\mathrm{N}^{\circ} 8$, pp 1691-1699. 